\title{
Application of meat and bone meals in agricultural ecosystems and their effect on the aquatic environment
}

\author{
A. Stepien ${ }^{1} \&$ S. Szymczyk ${ }^{2}$ \\ ${ }^{I}$ Department of Agriculture Systems, \\ University of Warmia and Mazury in Olsztyn, Poland \\ ${ }^{2}$ Department of Land Reclamation and Management, \\ University of Warmia and Mazury in Olsztyn, Poland
}

\begin{abstract}
The aim of this study was to verify the hypothesis that meat and bone meal, added to soil as fertilisers, may pose a hazard to the aquatic environment. Fertilisation with meat and bone meal and with manure resulted, on average, in an increase in mineral nitrogen concentration in underground water. It is noteworthy that phosphorus concentration in underground water on the plot fertilised with the highest dose of MBM increased by $79 \%$, as compared to the variant without fertilisation. The results achieved in the experiment indicate that supporting MBM fertilisation with potassium did not result in an increase in its concentration in underground water. On the contrary, the lowest concentration of potassium was determined in the underground water taken from the plots where $1.5 \mathrm{t}$ and $2.5 \mathrm{t}$ of MBM had been applied. Such results may be the consequence of a lack of potassium balance necessary to satisfy the nutritional needs of the crops. Introducing organic matter to soil as manure and MBM resulted in an increase in magnesium and calcium concentration in underground waters.
\end{abstract}

Keywords: meat and bone meal, MBM, farm yard manure, agricultural ecosystems, aquatic environment, fertilization.

\section{Introduction}

Nitrogen content in water at various stages of its hydrological circulation affects not only the productivity of soils, but also the eutrophic potential of water. Its 
level in underground waters depends, for example, on the substances released to the environment by agriculture and introduced with atmospheric precipitation [5]. The environmentally safe utilisation of organic waste is still a topical issue, despite numerous studies and recommendations based on their results. The amount of waste is constantly growing. What is changing is its mass within particular groups, which depends on the development tendencies and economic growth rates as well as social changes. One of the possibilities of utilisation of waste is its use for the improvement of soil fertility [3, 17]. The most frequently applied solution in the utilisation of meat and bone meal (MBM) is its incineration in cement plants and brickyards. However, this manner of waste utilisation is disputable due to its environmental aspects - hazards related to the emission of noxious gases during incineration. When applied to soil, MBM, as well as other organic fertilisers, improves its fertility, thereby positively affecting its physical, chemical and biological properties [1, 16]. Transformations of organic fertiliser give rise to products of humification and mineralization, which in natural conditions affect the circulation of nutrients and stability of ecosystems. Microbes make nutrients available to roots in a suitable form and in sufficient amounts, and the balanced nutrition of crops ensures their correct growth, which translates into high, good quality yield [2, 13]. The mass of organic fertilisers applied to soil affects the amount of mineral nitrogen available to plants $[10,15]$, as well as the organic carbon content $[9,12]$.

The aim of this study was to verify the hypothesis that MBM, added to soil as fertilisers, may pose a hazard to the aquatic environment.

\section{Materials and methods}

The results presented in this paper were achieved in a static field experiment, set up in a randomised blocks arrangement, conducted in the years 2007-2008 at the Production and Experimental Station in Balcyny near Ostroda. The experiment was set up in autumn 2005, in the landscape of ground moraine, within the Lubawski prominence in an area shaped during the period of Pomeranian glaciation of the Vistula River [8]. The experimental plot of 0.25 ha was situated in a slightly undulated area, with an inclination of about $3 \%$ and a north-eastern exposition. The experimental plot was characterised by low soil variability. The dominant type was grey-brown podsolic soil with the pseudogley sub-type, formed from light clay, and acid brown soil with the grain distribution typical of light clay. According to the soil quality classification, the soil was included in class IIIa (good arable land), while according to the soil agricultural classification it was classed as complex 4 - wheat-rye and, in a small part, as complex 2 - good wheat complex. The chemical analyses of the arable layers revealed that it was poor humous soil $(1.58 \%)$, acidic ( $\mathrm{pH}$ inKCl- 6.5$)$, with low nutrient content $\left(\mathrm{N}-0.91 \% ; \mathrm{P}-9.27 \mathrm{mg} \cdot 100 \mathrm{~g}^{-1 ;} \mathrm{K}-17.8 \mathrm{mg} \cdot 100 \mathrm{~g}^{-1} ; \mathrm{Mg}-5.72\right.$ $\left.\mathrm{mg} \cdot 100 \mathrm{~g}^{-1 ;} \mathrm{Ca}-56.0 \mathrm{mg} \cdot 100 \mathrm{~g}^{-1}\right)$.

The study was conducted in a four-course crop rotation, with the following crop sequence: spring wheat, faba bean, winter wheat, winter rape. Winter wheat was grown in 2007 and winter rape - in 2008. 
The following variants of fertilisation were applied: 1) " 0 " - control (without fertilization); 2) "FYM" - farm yard manure (10 tha ${ }^{-1,}$ per year); 3) "MMB-1.0" - MBM $1.0 \mathrm{t}^{-h^{-1}}$; 4) "MMB-1.5" - MBM $\left.1.5 \mathrm{t} \cdot \mathrm{ha}^{-1} ; 5\right)$ "MMB-2.0" - MBM 2,0 $\mathrm{t} \cdot \mathrm{ha}^{-1}$; 6) "MMB-2.5" - MBM $2.5 \mathrm{t} \cdot \mathrm{ha}^{-1}$ (per year). The following amounts of nutrients were added per $1 \mathrm{t}$ of MBM: $66.5 \mathrm{~kg} \cdot \mathrm{ha}^{-1} \mathrm{~N} ; 39.8 \mathrm{~kg} \cdot \mathrm{ha}^{-1} \mathrm{P} ; 4.1 \mathrm{~kg} \cdot \mathrm{ha}^{-1}$ $\mathrm{K} ; 2.0 \mathrm{~kg} \cdot \mathrm{ha}^{-1} \mathrm{Mg}$ i $19.0 \mathrm{~kg} \cdot \mathrm{ha}^{-1} \mathrm{Ca}$.

Due to the very low amounts of potassium in MBM, mineral potassium fertilisation was applied as $50 \%$ potassium salt at $50 \mathrm{~kg} \cdot \mathrm{ha}-1 \mathrm{~K}$. The following were added to the soil with $10 \mathrm{t}$ of manure (fresh mass): -

Ground water for analyses was collected in 1 month cycles (from March to October) from piezometric boreholes. The following were determined in each: $\mathrm{pH}$ value - potentiometrically; electrical conductivity - conductometrically; dry residue content - after evaporation and drying at $105^{\circ} \mathrm{C}$ and ash content - after incineration in a muffle furnace at $550^{\circ} \mathrm{C}$; mineral nitrogen (as the sum of nitric nitrogen (V) - colorimetrically with disulphophenolic acid, nitric nitrogen (III) colorimetrically with sulphanilic acid and ammonium nitrogen - colorimetrically with Nessler's reagent), total phosphorus - after mineralization with ammonium molybdenate and tin (II) chloride as the reducer, magnesium - colorimetrically with titanium yellow, and potassium, sodium and calcium - by atomic emission spectroscopy.

The rainfall during the period of the study (2007-2008) varied, both from year to year and from month to month within a year (Fig. 1).

This affected the level of underground waters. The total rainfall in 2008 was similar to that in the period 1961-1995. Much more rainfall was recorded in 2007 - it was over 30\% higher than in the period 1961-1995 and in 2008.

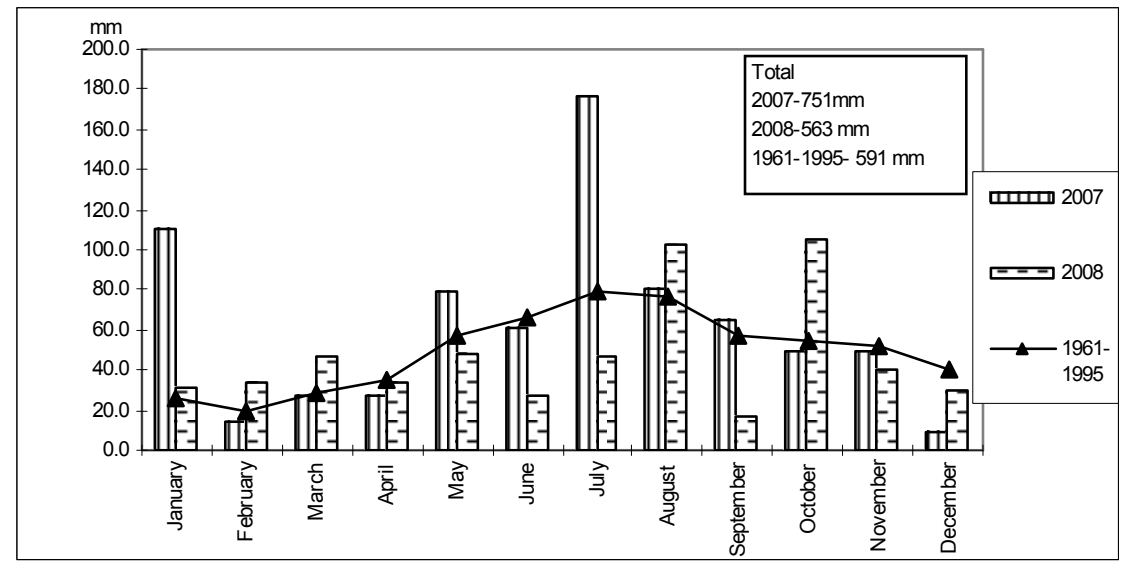

Figure 1: Rainfall distribution on the Meteorological Station at Balcyny. 


\section{Results and discussion}

Fertilisation with $\mathrm{MBM}$ resulted in a $21 \%$ increase in the mineral nitrogen content in the underground water (Fig. 2). However, the effect of particular doses of MBM was not so clear. Its application at $1.0 \mathrm{t}$ and $1.5 \mathrm{t}$ resulted in an $18 \%$ decrease in mineral nitrogen as compared to the control. However, the application of MBM at $2.0 \mathrm{t}$ increased the mineral nitrogen content in water by $8 \%$ as compared to the control. The application of $2.5 \mathrm{t}$ of MBM resulted in a $111 \%$ increase in mineral nitrogen concentration in underground water. This is a consequence of the application of $166 \mathrm{~kg}$ of nitrogen each year. The nitrogen is biologically bound and it becomes available to plants only after it has been transformed by microbes in soil. Nitrogen abundance in soil is correlated with the content and availability of organic matter [10], fertilisation with mineral nitrogen [7] and plants' ability to take it up from soil [5]. Therefore, it is not surprising that the nitrogen content in the underground water on the plots fertilised with organic fertilisers is higher. According to Maćkowiak [12], nitrogen in meals of animal origin is in an organic, slow-acting form. He assumed a weaker fertilising action of MBM than that of manure, adopting the equivalent $=20$. For example, the content of total nitrogen in 5 tonnes of an improver is $350 \mathrm{~kg}$, which is equivalent to $70 \mathrm{~kg}$ of active nitrogen.



Figure 2: The effect of fertilisation with MBM on the content of mineral nitrogen in underground waters.

Applying large amounts of biological nitrogen (43.3kg of $\mathrm{N}$ per ha per year) to a plot fertilised with $10 \mathrm{t} \cdot \mathrm{ha}^{-1}$ of manure resulted in an $81 \%$ increase in the mineral nitrogen content in the underground water. The mass of organic fertilisers applied to the soil determines the amount of mineral nitrogen, available to plants $[2,14]$. The results indicate an increase in the mineral nitrogen content in the underground water on the plots where MBM was applied, which confirms the findings of Jeng et al. [6]. They observed that the application of animal meal increased the amount of absorbable forms of nitrogen, which 
forms the sorptive complex. Blatt and McRae [1] also claim that when applied regularly, animal meal produces an increase in organic matter and total nitrogen content in soil.

According to Maćkowiak [12], MBM contains 2.6-4.7\% phosphorus in 91.3$97.0 \%$ air-dry matter. The chemical analyses conducted in this experiment have shown that the highest amount of phosphorus of $99.5 \mathrm{~kg} \cdot \mathrm{ha}^{-1}$ reached the soil with $2.5 \mathrm{t}^{\mathrm{tha}} \mathrm{h}^{-1}$ of MBM (Fig. 3). This was reflected in the amount of phosphorus filtering through to the underground water. A noteworthy value is the $79 \%$ increase in phosphorus content in the underground water on the plot fertilised with the highest dose $\left(2.5 \mathrm{t} \cdot \mathrm{ha}^{-1}\right)$ of MBM, as compared to the variant without fertilisation. There are no available data on the effect of MBM on phosphorus content in underground water; however, as comparable results achieved by Blatt [1] show, the application of meal results in an increase in absorbable forms of phosphorus in soil. Different results were achieved on the plot where $2.0 \mathrm{t}^{\mathrm{hah}} \mathrm{h}^{-1}$ of MBM was applied; the phosphorus content was the lowest in the entire experiment, including the plot with no fertilisation. However, the differences were statistically insignificant.



Figure 3: The effect of fertilisation with MBM on the content of total phosphorus in underground waters.

The concentration of potassium in the underground water from the experimental plots was completely different from the corresponding values for phosphorus, as its highest content was determined on a plot where no fertilisation had been applied (Fig. 4). As was mentioned in the experiment methodology, due to the low concentration of potassium in the MBM, additional potassium fertilisation was applied at $50 \mathrm{~kg} \cdot \mathrm{ha}^{-1} \mathrm{~K}$. The results indicate that even when the MBM fertilisation is supported with a potassium fertiliser, no increase in potassium content in the underground water is observed. On the contrary, the lowest potassium concentration was determined in the underground water taken from the plots fertilised with MBM at $1.5 \mathrm{t}^{-\mathrm{ha}^{-1}}$ and $2.5 \mathrm{t} \cdot \mathrm{ha}^{-1}$. A lower 
concentration, by $0.25 \mathrm{mg} \cdot \mathrm{dm}^{-3}$, was determined in variants with 1.0 and $2.0 \mathrm{t}$ of MBM per ha. Such values may result from a lack of balance of the potassium needed to satisfy the nutritional needs of the crops (winter wheat and winter rape) [4]. The same explanation may be adopted for the plot fertilised with manure, which added $54.3 \mathrm{~kg}$ of $\mathrm{K}$ per ha per year, where the potassium content was also found to be lower than on the control plot. Therefore, these are the amounts of potassium which are insufficient to satisfy the nutritional needs of the crops.

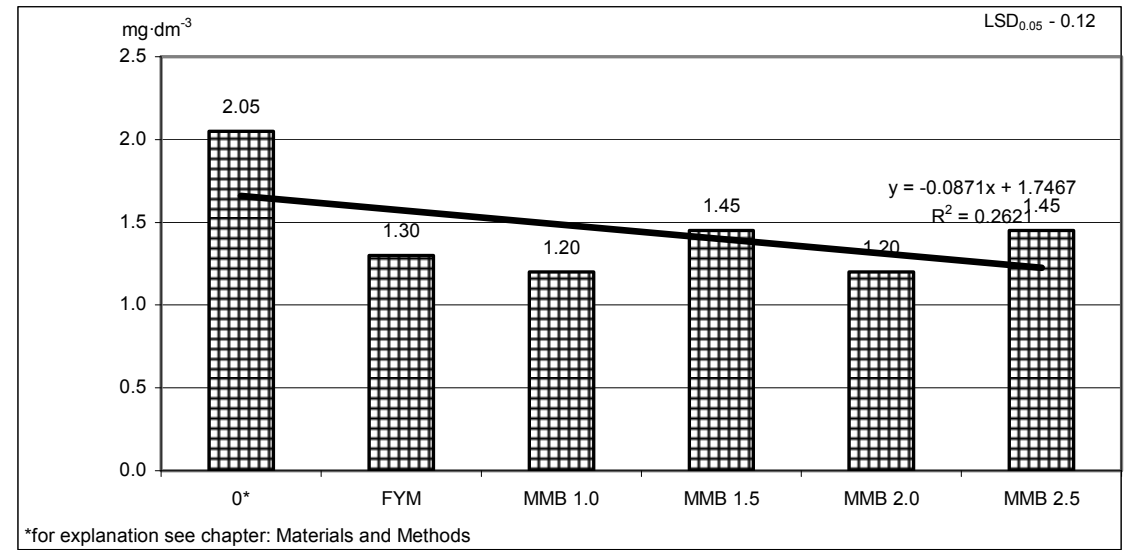

Figure 4: The effect of fertilisation with MBM on the content of total potassium in underground waters.

The addition of organic matter to soil as manure and MBM resulted in $41 \%$ increase in magnesium concentration in underground water, on average (Fig. 5). The lowest, a $32 \%$ increase, was observed when the lowest dose of $1.0 \mathrm{t}$ of MBM per ha was applied. Further increasing the dose of MBM to $1.5 \mathrm{t}$ resulted only in a $4 \%$ increase in magnesium concentration as compared to the dose of 1.0 t. The MBM dose of $2.0{\mathrm{t} \cdot h \mathrm{a}^{-1}}^{1}$ resulted in a $13 \%$ increase in magnesium concentration as compared to the lowest dose. The results of chemical analyses show that 2 to 5 times more magnesium is introduced to the soil with manure than with the lowest dose of MBM. However, this did not result in a higher extent of magnesium leaching from the plot fertilised with manure. The average concentration of magnesium in underground waters on the plot fertilised with manure was lower than on that fertilised with MBM. However, the difference was only significant after higher doses of MBM (2.0 and $\left.2.5 \mathrm{t}^{\text {tha }}{ }^{-1}\right)$ were applied.

A comparison of the average values shows that organic fertilisation resulted in an irregular increase in calcium concentration in the underground water (Fig. 6). The average values were about 50\%. The highest amount of calcium $47.5 \mathrm{~kg}$, was introduced to the soil with the largest dose $\left(2.5 \mathrm{t} \cdot \mathrm{ha}^{-1}\right)$ of MBM. The calcium concentration on the plot was found to have increased by $94 \%$ as compared to the plot with no fertilisers. The second highest concentration of calcium was found in the water taken from piezometers situated on the plot 
fertilised with MBM at $1.0 \mathrm{t} \cdot \mathrm{ha}^{-1}$. This result slightly deviated from the principle according to which the higher amount of calcium added, the higher amount of calcium leached from soil to water. Evidence of this is a lower concentration of calcium on the plots fertilised with $1.5 \mathrm{t}$ and $2.0 \mathrm{t} \cdot \mathrm{ha}^{-1}$ than on the plot fertilised with the lowest dose of MBM, with the lowest amount of calcium introduced to the soil with the fertiliser. Application of manure also increased calcium leaching to underground water by $44 \%$ as compared to the control plot. However, the total value was lower than on the plot fertilised with MBM. The dose of MBM comparable to the effect of manure on calcium leaching was 1.5 and $2.0 \mathrm{t} \cdot \mathrm{ha}^{-1}$.

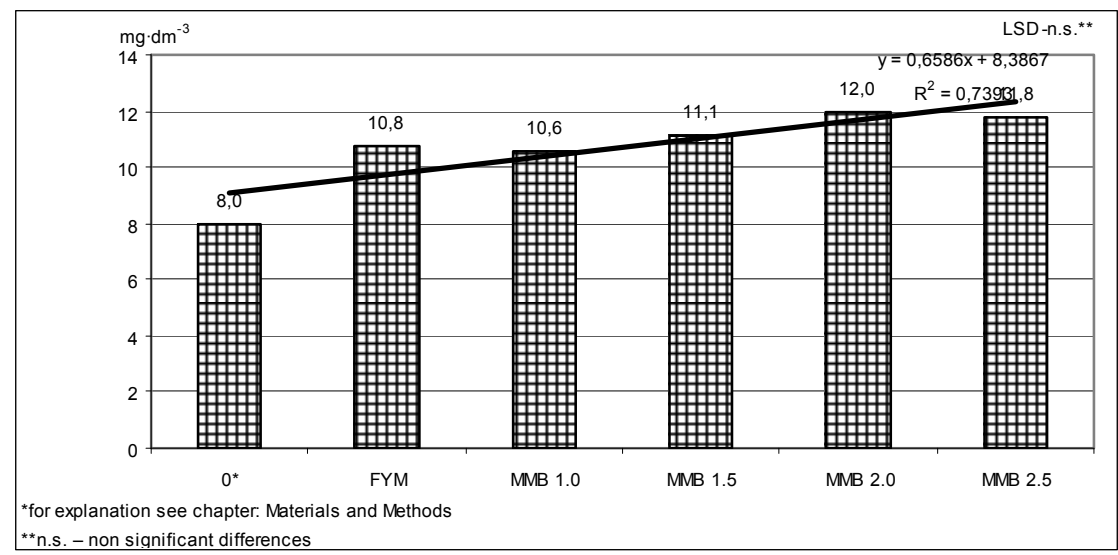

Figure 5: The effect of fertilisation with MBM on the content of total magnesium in underground waters.

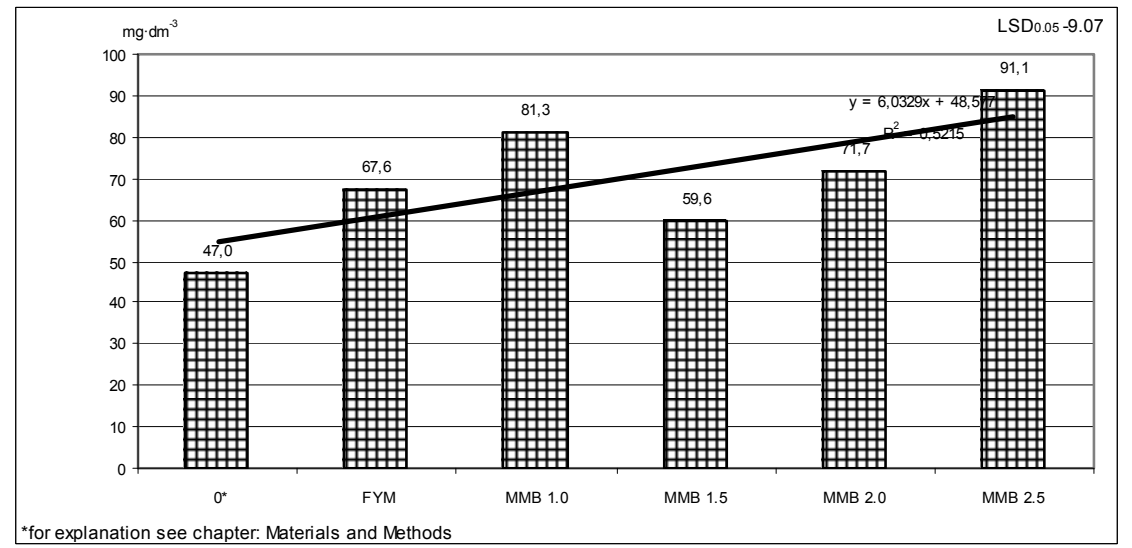

Figure 6: The effect of fertilisation with MBM on the content of total calcium in underground waters. 


\section{Conclusions}

1. Fertilisation with MBM and with manure resulted, on average, in an increase in mineral nitrogen concentration in underground water.

2. It is noteworthy that phosphorus concentration in underground water on the plot fertilised with the highest dose of MBM, increased by $79 \%$ as compared to the variant without fertilisation.

3. The results achieved in the experiment indicate that supporting MBM fertilisation with potassium did not result in an increase in its concentration in underground water. On the contrary, the lowest concentration of potassium was determined in the underground water taken from the plots where $1.5 \mathrm{t} \cdot \mathrm{ha}^{-1}$ and $2.5 \mathrm{t} \cdot \mathrm{ha}^{-1}$ of MBM had been applied. Such results may be the consequence of a lack of potassium balance necessary to satisfy the nutritional needs of the crops.

4. Introducing organic matter to soil as manure and MBM resulted in an increase in magnesium and calcium concentration in underground waters.

\section{Acknowledgement}

The publication has been co-funded by the Ministry of Science and Higher Education of the Republic of Poland as part of project N 310 082 32/3238.

\section{References}

[1] Blatt. C. R., McRae K. B. Comparison of four organic amendments with a chemical fertilizer applied to three vegetables in rotation. Canadian Journal of Plant Science. 78(4), pp. 641-646, 1998.

[2] Chambers B.J., Wiliams J.R., Smith K.A., Van-Cleemput O., Hofman G., Vermoesen A. Residual effects of poultry manure and fertilizer nitrogen applications. Progress in nitrogen cycling studies. Proc. of the 8th Nitrogen Workshop held at the University of Ghent, 5-8 September 1994. pp. 183$190,1996$.

[3] Dechnik I., Skowrońska M. Wpływ uciążliwych odpadów organicznych na niektóre właściwości fizykochemiczne i chemiczne gleby. Folia Univ. Agric. Stetin. 211 Agricultura (84), pp. 91-94, 2000.

[4] Fotyma M., Mercik S. Chemia rolna. PWN 2000. Warszawa.

[5] Haag D \& Kaupenjohann M. Landscape fate of nitrate fluxes and emissions in Central Europe-A critical review of concepts, data, and models for transport and retention, Agr. Ecosyst. Environ. 86 (1), pp. 1-21, 2001.

[6] Jeng A., Haraldsen T. K., Vagstad N., Gronlund A. Meat and bone meal as nitrogen fertilizer to cereals in Norway. Agricultural \& Food Science. 13(3), pp. 268-275, 2004.

[7] Kaniuczak J. Bilans azotu, fosforu, potasu, magnezu w glebie lessowej w warunkach nawożenie organiczno-mineralnego. Zesz. Nauk AR Szczecin, 172, Rolnictwo 62, pp. 189-195, 1996.

[8] Kondracki J. Geografia regionalna Polski. PWN, Warszawa, 2001. 
[9] Körschens M., Dhaliwal G.S., Arora R., Randhawa N.S., Dhawan A.K. Possibilities and limits of carbon accumulation in arable soils. Ecological agriculture and sustainable development: volume 1. Proc. of International Conference on ecological agriculture. Chandigarh, India, 15-17 November 1997, pp. 536-543, 1998.

[10] Krzywy E., Krupa J., Wołoszyk C. Wpływ wieloletniego nawożenia organicznego i mineralnego na niektóre wskaźniki żyzności gleby. Zesz. Nauk AR Szczecin 172 Rolnictwo 62, pp. 259-264, 1996

[11] Lazarovits G. Management of soil-borne plant pathogens with organic soil amendments: A disease control strategy salvaged from the past. Canadian Journal of Plant Pathology. 23(1), pp. 1-7, 2001.

[12] Maćkowiak Cz. Mączki mięsne na pola. Top Agrar Polska. Nr 3, pp. 158$160,2005$.

[13] Nowak W., Sowiński J. Zmiany odczynu oraz zawartość niektórych składników gleby podczas wegetacji buraka cukrowego. Zesz. Nauk. AR Wrocław, Rolnictwo 63, pp. 55-66, 1995.

[14] Sakamoto K., Kamakura J. Effects of application of organic, fermentedorganic, mixed and inorganic fertilizers on soils and apple trees. Bulletinof-the-Aomori-Apple-Experiment-Station. (33), pp. 51-91, 2002.

[15] Sołtysiak U. Rolnictwo ekologiczne. Od producenta do konsumenta. Wyd. Ekoland. Warszawa, 1995.

[16] Verentreten R., Goffart J.P., Hofman G. Azote mineral dans le profil du sol. Betteravier-Bruselles 31, 325, pp. 24-26, 1997.

[17] Zięba S. Ważna konferencja na SGGW o problemach utylizacji w przemyśle mięsnym. Pasze Przemysłowe 1, pp. 15-19, 2004. 